\title{
Indigenous Plant Utilization and Farming System of Garo Tribe in North-East Bangladesh: a Means of Sustainable Biodiversity Conservation
}

Md. Habibur Rahman and Most. Jannatul Fardusi*

Department of Forestry and Envirommental Science, School of Agriculture and Mineral Sciences, Shahjalal University of Science and Technology, Sylhet 3114, Bangladesh

\begin{abstract}
A special type of indigenous knowledge on plants utilization and farming system was explored by the Garo tribe community in the North-East region of Bangladesh, which correspond to the severe dependence on homestead forest. Results show that the Garo are totally dependent on the natural resources and that the extent of their dependency is faithfully reflected in their ethno-botanical knowledge. Dependencies that the study addressed focused on various aspects of food, fruit, energy, timber and health care on plants products. Garo tribe community in Bangladesh followed agrosilvipastoral system in their homesteads. They have indigenous hunting procedure to trap the animal in the forest. A total of 9 foods, 15 fruits, 12 energy-producing and 11 timber species was found and recorded that the Garo used in their daily life. Moreover, Garo used 23 medicinal plants species and have vast indigenous knowledge about using herbal medicine in daily health care practices. The Garo women do mostly the household activities, managing homestead forest and helping agricultural field where men perform all hard working activities like ploughing, cutting trees, digging the soil, preparation of horticultural and agricultural land, hunting, etc. The overall quality of life of the Garo could be considerably upgraded if ethno-botanical issues and their own indigenous knowledge will complement with scientific knowledge. The findings of the study conclude that the conservation of the indigenous knowledge of the Garo tribe related to plants utilization can also be turned to good account in forest conservation and is an important tool in this tribal area of Bangladesh.
\end{abstract}

Key Words: agroforestry, indigenous knowledge, food habit, fruit consumption, medicinal plants, gender role

\section{Introduction}

The Garos are one of the well-known ethnic communities of the Indian subcontinent. Their present population around the world is approximately half a million; most of them are living in Northeastern India mainly in Garo hills
(Chowdhury 2007). Nowadays, about one-fifth of the total population of the Garos lives in Bangladesh which constitute less than one percent of the total population of the country. Garos are mostly known to the outside world for their matrilineal social organization especially for their distinct kinship system (Burling 1997). The people who are

Received: August 27, 2011. Revised: April 25, 2012. Accepted: May 8, 2012.

Corresponding author: Most. Jannatul Fardusi

Department of Forestry and Environmental Science, School of Agriculture and Mineral Sciences, Shahjalal University of Science and Technology, Sylhet 3114, Bangladesh

Tel: 880-1675257751, E-mail: jfardusi@yahoo.com 
known as Garo to outsides prefer to call themselves Achik (the Hilly Garos prefer to call themselves 'Achik') and Mandis (plain land Garos called themselves 'Mandi') but all these people are known as 'Garo' to the outsiders (Bleie 2005). In fact, in Bangladesh most of the Garos are living in the plain lands. They have their own language, culture, shared history and experiences. Their mother tongue is Garo, which belongs to the Bodo group of Tibeto-Burman stock (Burling 1997). Traditionally, Garos have many festivals and ceremonies which are mostly connected with various phases of cultivation and harvesting as they are agriculture based, but in earlier days they had (it is said) some cruel beliefs and practices, such as human head hunting and others which have now stopped (Chowdhury 2007). Garos' main festivals are: Wangala, Rangchugala, Agalmaka, Michitata, Gitchingpong and recently the Celebration of Christmas (Banglapedia 2006). Today most of the Garos are Christian. Bal (2000), describes, 'Today Christianity is of great importance to the Garo community and more than ninety percent of the Garos proudly consider themselves Christian'.

Garos are concentrated mainly in Tangail, Mymensingh, Netrokona and Jamalpur district of Bangladesh. Garos have their own indigenous knowledge to manage natural resources for their livelihoods. The main livelihood activities of Garos are agricultural practices in the plain land, homestead and in the forest land. Once they were accustomed to Jhum farming, but now they follow plough cultivation in plain land by transplanting rice. But they managed their homesteads and forest land as agroforestry system namely agrosilvipastoral system and agrisilvicultural system and woodlot plantation respectively. They also have developed indigenous knowledge system of their own in practicing the special type of utilization pattern of forest produces (Alam and Khisa 2000; Rashid and Rashid 2002; Ahmed 2003; Anon 2003; Nasrin and Khalifa 2004). Today most of the wealth of indigenous knowledge of the Garo community in Bangladesh is being threatened by the settlements of the non-tribal people in the region.

It was hypothesized that the Garo community encompassed a particular type of utilization and dependence on trees including indigenous knowledge. Several studies have been carried out with various tribes regarding the exploration of ethno-forestry and indigenous knowledge in
Bangladesh (Banik 1998; Khisa 1998; Sattar 1998; Siddiqi 1998; Alam and Khisa 2000; Haque 2000a, 2000b; Alam 2002; Mohiuddin et al. 2002; Mustafa et al. 2002; Miah and Chowdhury 2003; Miah and Chowdhury 2004; Partha and Hossain 2007; Rana et al. 2009; Uddin et al. 2009; Rana et al. 2010; Rahman et al. 2011). But the indigenous knowledge of plants utilization and farming system of Garo tribe were ignored earlier despite they were the original forest dwellers in East instead of east region of Bangladesh. The Garo have special and particular relationship and dependency on forest for their daily needs. However, due to the isolation and the relative inaccessibility of the Garo, no study has yet been carried out on their agroforestry practices, homestead management, dependency and utilization pattern of trees, which is why the present study was undertaken in the East instead of east region (Netrokona district) of Bangladesh.

\section{Study Area}

The study was conducted at Durgapur upazila (sub-district; an administrative entity) of Netrokona district in the division of Dhaka, Bangladesh (Fig. 1) with an area of $293.42 \mathrm{~km}^{2}$. It is located between $25.1250^{\circ} \mathrm{N}, 90.6875^{\circ} \mathrm{E}$ (BBS 2005). It is bounded by Meghalaya (State of India) on the north, Netrokona Sadar and Purbadhala upazilas on the south, Kalmakanda upazila on the east, Dhobaura upazila on the west (Banglapedia 2000). Geologically the area is almost uniform (Rashid 1991). Topographically the area is characterized by its large platen like hillock, known as tilla. The drainage pattern of the area is dentric. The soil pattern of the Durgapur is complex. Most of the upland has deep, moderately well drained permeable clay with heavy clay in the valleys. Some of the upland has impervious clayey sub soil. Soil pH varies from 6 to 6.5 (Rashid 1991). The area lies in the semi drier part of the Bangladesh. The maximum temperature is usually $30^{\circ} \mathrm{C}$ during the month of May and maximum temperature is about $10^{\circ} \mathrm{C}$ during the month of January (BBS 2005).

\section{Survey Methods}

Among ten upazila of Netrokona district, the study area was selected purposively in Durgapur upazila because the 


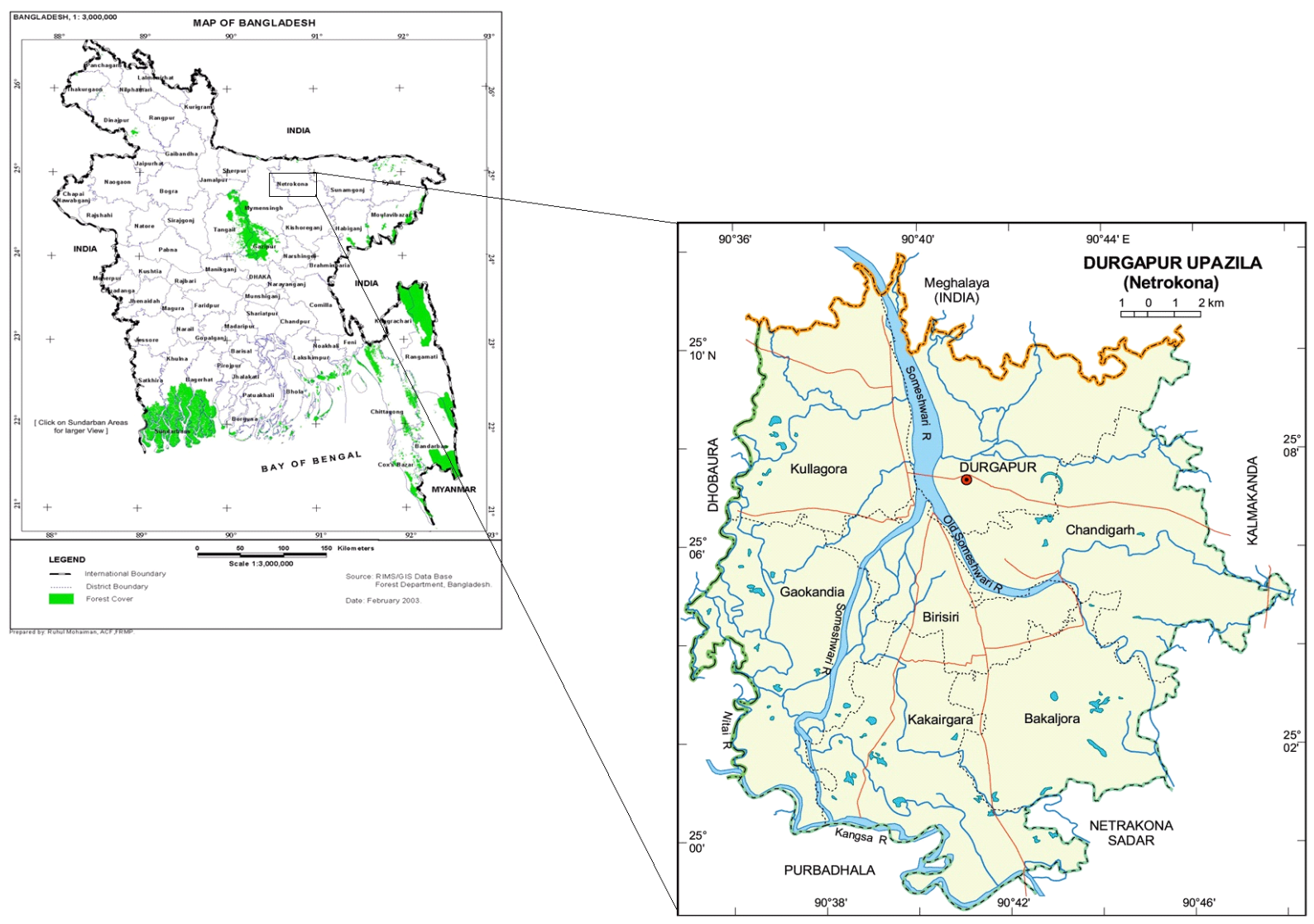

Fig. 1. Map of the study area.

Garo are concentrated in this area. There are two tribes in this district namely Garo and Hajong. We collected the list of Garo villages from Durgapur upazila statistics office. There were five villages in where Garos are dominant. Two villages namely Fulbari and Nollapara were selected randomly. We found 100 Garo households in these two villages. Data were collected both by the interview and from direct observation during July 2010 to December 2010. A total of 40 households were selected randomly, with a total population of 260 for interviewing. Sampling intensity was $40 \%$.

Before households were sampled, a formal discussion was held at the local union (a rural administrative unit consist of a number of villages) council office with the local representative in Chairman and Members of the local union council. The village headman and the members of the farmers group and other influential persons e.g. school teacher and the NGO officers. The objectives of this work were to explain the work indented and to identify two suitable research associate to assist the study. The following criteria were taken into consideration while recruiting the associates. They are community members, literate and able to communicate in local dialect and are willing to work with local community.

A preliminary socio-economic survey was carried out to ascertain important socio-economic parameters of the study area to select respondents for detailed study. The households were surveyed completely at that stage. A semi-structured questionnaire was used for the survey, worked out in advance and pre-tested for intelligibility. On each topic the respondents were free to express his/her views. The survey was designed to gather information relating to: family size, household composition, educational status, total annual income, occupation of the respondents, different cultural activities, total land holdings, farming system of house and agrifields, division of labor, collected material from the for- 
est, myth an belief about trees and their and marketing of their farm product, etc. Household heads (in this case all were male) were the respondents of the study and they were helped from other family members where it was deemed necessary.

First of all, species used for food, fruit, energy, timber, basketry, utensils and festivals were collected under their local names. A field-visit was then arranged to the forest and homestead with the relevant respondents and other key persons to ascertain the Bengali and scientific name. Following this, a list of the species used for various purposes was prepared using Das and Alam (2001); Dey (2006) as the basis of reference. The various parts of the plant species used for food and fruit were ascertained with the several physical observations in the Garo house. The baskets and utensils made of forest products were checked to corroborate the interview and plants used for festivals also were crosschecked with several physical observations.

\section{Results and Discussion}

\section{Homestead agroforestry}

From the ancient time Garo tribe in Bangladesh used homestead agroforestry system. They follow agrosilvipastoral system in their homesteads. Seed, seedling and vegetative propagules are used generally to generate the plant in their homestead. They broadcast or put the seeds in a certain place and watering. After germination watering continued and keeps it free from goat and other cattle. Sometimes they throw the seeds after consuming the fruits. Some trees are grown from vegetative propagules for budding grafting and cutting. Sometimes they collect vegetative propagules which produced from root such as Teak (Tectona grandis), Kachu (Colacasia esculenta) and Kola (Musa spp.) etc. There are three main components of this system namely trees, crops and livestock's. Table 1 enlisted the plant and crop species found in the surrounding homestead of Garo tribe community in the study area. Contemporary, the main livestock rearing in the Garo's homestead were found Sus Scrofa (34\%), Gallus gallus (33\%), Boss Indica (17\%), Anas poecilorhyncha (9\%) and Capricorins sumatrensis (7\%), etc.

\section{Participatory agroforestry}

Since 1990 woodlot plantation was started by the forest department in the border line hillocks of the study area. Most of the land property of the forest department is used as participatory agroforestry by the Garos. Local forest department, settlers and the Garo are the key component of this program. Total area of woodlot plantation is 100 hectares and total 100 participants were engaged. Each participant gets one hectares land year to year as a renewable basis and they follows the agrisilvicultural system in this land according to the suggestions by the forest department. They plant different types of tree and crops species in the restricted land. They get whole benefit from the medicinal and horticultural species. About 21 tree species and 9 crop species were found during the survey in the woodlot plantation (Table 2).

The plantation established on participatory basis are being harvested at the end of rotation and the sale proceeds are distributed on the basis of benefit sharing agreement approved by the Apex Body as follows: Forest department $30 \%$, beneficiaries $60 \%$, tree farming fund (TFF) $10 \%$. This sharing agreement is documental and it is delivered to all participants. TFF is kept to a committee and spend to establish and maintain new plantation. The participants get several technical supports from forest department. Proper training on how to plant and maintain the plantation is given to them by the forest department. Planting materials such as fertilizer, stick, strings are also provided to them. Protection from pest, disease and mortality and vacancy filling are done by the forest department.

\section{Food habit}

Study found that rice is the main staple food of the Garo tribe; getting three times in a day at morning, noon and night. In addition with rice; fish, meat, vegetables, eggs were regarded as side dish. Oil, salt, chilly, zinger, turmeric and various kinds of spices and condiments were found to be used as condiments in cooking the vegetables and curry to increase its taste and delicacy. Green chilies are very common as a condiment. They take all type of flesh e.g. beef, pork, mutton, duck, chicken and various other fleshes. It may be bird, reptile etc. Men and women drink homemade intoxicating liquors or rice beer $(C h u)$ especially during 
Table 1. List of plant and crop species found in the home garden of Garo tribe of Bangladesh

\begin{tabular}{|c|c|c|c|c|c|}
\hline & Local name & Scientific name & Family & Preference & Occurrence \\
\hline \multirow[t]{10}{*}{ Tree species } & Akashmoni & Acacia auriculiformis Willd. & Mimosaceae & +++ & $\mathrm{C}$ \\
\hline & Eucalyptus & Eucalyptus camaldulensis Dehnhardt. & Myrtaceae & ++ & $\mathrm{C}$ \\
\hline & Gamar & Gmelina arborea (Roxb.) DC. & Verbanaceae & +++ & $\mathrm{C}$ \\
\hline & Jarul & Lagerstroemia speciosa (Linn.) Pers. & Lythraceae & ++ & $\mathrm{FC}$ \\
\hline & Jiga & Lannea coramandelica (Houtt.) & Anacardiaceae & + & $\mathrm{R}$ \\
\hline & Mahagoni & Srwietenia mahogany (Linn.) Jacq. & Meliaceae & +++ & $\mathrm{C}$ \\
\hline & Rain tree & Samanea saman (Jaq.) Merr. & Mimosaceae & ++ & $\mathrm{C}$ \\
\hline & Segun & Tectona grandis L. instead of Linn. & Verbenaceae & +++ & $\mathrm{C}$ \\
\hline & Sil koroi & Albizia procera Benth. & Mimosaceae & ++ & $\mathrm{FC}$ \\
\hline & Sissoo & Dalbergia sissoo Roxb. & Fabaceae & + & $\mathrm{C}$ \\
\hline \multirow[t]{11}{*}{ Fruit species } & $\mathrm{Am}$ & Mangifera indica Linn. & Anacardiaceae & +++ & $\mathrm{C}$ \\
\hline & Bel & Aegle marmelos (Linn.) Correa. & Rutaceae & ++ & $\mathrm{FC}$ \\
\hline & Boroi & Zizyphus mauritiana Lamk. & Rhamnaceae & ++ & $\mathrm{FC}$ \\
\hline & Chalta & Dillenia indica Linn. & Dilleniaceae & + & $\mathrm{FC}$ \\
\hline & Jalpai & Elaeocarpus floribundus Blume. & Elaeocarpaceae & + & $\mathrm{R}$ \\
\hline & Jam & Syzygium cumini (Linn.) Skeel. & Myrtaceae & +++ & $\mathrm{C}$ \\
\hline & Jambura & Citrus grandis (Linn.) Osbeck. & Rutaceae & + & $\mathrm{FC}$ \\
\hline & Kanthal & Artocarpus heterophyllus Lamk. & Moraceae & +++ & $\mathrm{C}$ \\
\hline & Peyera & Psidium guajava (Linn.) Bat. & Myrtaceae & +++ & $\mathrm{C}$ \\
\hline & Supari & Areca catechu Linn. & Arecaceae & +++ & $\mathrm{C}$ \\
\hline & Tentul & Tamarindus indica Linn. & Caesalpiniaceae & ++ & $\mathrm{C}$ \\
\hline \multirow[t]{11}{*}{ Medicinal plants } & Amloki & Phyllanthus embelica Linn. & Euphorbiaceae & + & $\mathrm{FC}$ \\
\hline & Arjun & Terminalia arjuna $\mathrm{W} \& \mathrm{~A}$ & Combretaceae & ++ & $\mathrm{FC}$ \\
\hline & Basok & Adhatoda vasica Nees & Acanthaceae & + & $\mathrm{FC}$ \\
\hline & Bohera & Terminalia belerica Roxb. & Combretaceae & + & $\mathrm{R}$ \\
\hline & Durba grass & Cynodon dactylon (Linn.) Pers. & Poaceae & +++ & $\mathrm{C}$ \\
\hline & Horitaki & Terminalia chebula (Gaerth.)Retz. & Combretaceae & + & $\mathrm{R}$ \\
\hline & Neem & Azadirachta indica A. Juss. & Meliaceae & +++ & $\mathrm{C}$ \\
\hline & Shatamuli & Asparagus racemosus Willd. & Asparagaceae & + & $\mathrm{R}$ \\
\hline & Thankuni & Centella asiatica (Linn.) Urban & Umbelliferae & +++ & $\mathrm{FC}$ \\
\hline & Tulsi & Ocimum sanctum Linn. & Labiatae & +++ & $\mathrm{C}$ \\
\hline & Ulotkombal & Abroma augusta Linn. & Sterculiaceae & + & $\mathrm{R}$ \\
\hline \multirow[t]{4}{*}{ Horticulture } & Anaros & Annas comosus (Linn.) Marr. & Bromeliaceae & +++ & $\mathrm{C}$ \\
\hline & Kola & Musa spp. & Musaceae & +++ & $\mathrm{C}$ \\
\hline & Lebu & Citrus limon (Linn.) Burm.f. & Rutaceae & +++ & $\mathrm{C}$ \\
\hline & Papaya & Carica papaya Linn. & Caricaceae & +++ & $\mathrm{C}$ \\
\hline \multirow[t]{6}{*}{ Root crops } & Ada & Zingiber otficinale Roscoe & Zingiberaceae & +++ & $\mathrm{C}$ \\
\hline & Halud & Curcuma longa Linn. & Zingiberaceae & +++ & $\mathrm{C}$ \\
\hline & Mati alo & Dioscorea bulbifera Linn. & Dioscoreaceae & + & $\mathrm{R}$ \\
\hline & Misti alo & Dioscorea alata Linn. & Dioscoreaceae & + & $\mathrm{FC}$ \\
\hline & Piaj & Allium cepa Linn. & Liliaceae & +++ & $\mathrm{C}$ \\
\hline & Rashon & Allium sativum Linn. & Liliaceae & + & $\mathrm{C}$ \\
\hline
\end{tabular}

their cultural festival. These are prepared from rotten rice. $C h u$ is their most favorite drinking item without drinking $C h u$ any kind of function or ceremonies remains incomplete. They also take tea every day in their houses and men and women of old ages take betel leaf with tobacco, nut, lime and khoir (a thin coating of catechu). Along with those foods, the Garo were also reported to consume wild animals like pig by hunting. In one month they could catch four to 
Table 1. Continued

\begin{tabular}{|c|c|c|c|c|c|}
\hline & Local name & Scientific name & Family & Preference & Occurrence \\
\hline \multirow[t]{11}{*}{ Vegetables } & Bagon & Solanum melongena Wall. & Solanaceae & +++ & $\mathrm{C}$ \\
\hline & Derosh & Abelmoschus esculentus (Linn.) Moench, Meth. & Lamiaceae & ++ & $\mathrm{FC}$ \\
\hline & Kachu & Colacasia esculenta Schott. & Araceae & ++ & $\mathrm{FC}$ \\
\hline & Lal shak & Amaranthus tricolor Linn. & Amaranthaceae & +++ & $\mathrm{C}$ \\
\hline & Lau & Lagenaria siceraria (Molina) Standl. & Cucurbitaceae & ++ & $\mathrm{C}$ \\
\hline & Maskolai & Phaseolus mungo Linn. & Legumominosae & ++ & $\mathrm{FC}$ \\
\hline & Misti kumra & Cucurbita maxima Duch. ex Lamk. & Cucurbitaceae & ++ & $\mathrm{C}$ \\
\hline & Morich & Capsicum frutescens Linn. & Solanaceae & +++ & $\mathrm{C}$ \\
\hline & Palongsak & Spinaceae oleracea Linn. & Chenopodiaceae & + & $\mathrm{FC}$ \\
\hline & Poisak & Basella rubra Linn. & Begoniaceae & ++ & $\mathrm{FC}$ \\
\hline & Sim & Lablab purpureus (Linn.) Sweet & Fabaceae & ++ & $\mathrm{FC}$ \\
\hline
\end{tabular}

Preference: +++ High, ++ Medium, + Low; Occurrence: C-common, FC-fairly common, R-rare.

Table 2. Plant species composition of agrisilvicultural system practiced by Garo tribe

\begin{tabular}{|c|c|c|c|}
\hline Species & Local name & Scientific name & Family \\
\hline \multirow[t]{7}{*}{ Timber species } & Akashmoni & Acacia auriculiformis Willd. & Mimosaceae \\
\hline & Gamar & Gmelina arborea (Roxb.) DC. & Verbanaceae \\
\hline & Mahagoni & Swietenia mahogany (Linn.) Jacq. & Meliaceae \\
\hline & Rain tree & Samanea saman (Jaq.) Merr. & Mimosaceae \\
\hline & Segun & Tectona grandis L. f. & Verbenaceae \\
\hline & Sil koroi & Albizia procera Benth. & Mimosaceae \\
\hline & Sissoo & Dalbergia sissoo Roxb. & Fabaceae \\
\hline \multirow[t]{3}{*}{ Cultivated } & Bansh & Bambusa spp. & Gramineae \\
\hline & Cane & Calamus spp. & Palmae \\
\hline & Murta & Schumannianthus dichotomus & Marantaceae \\
\hline \multirow{6}{*}{ Fruit species } & $\mathrm{Am}$ & Mangifera indica Linn. instead of L. & Anacardiaceae \\
\hline & Jalpai & Elaeocarpus floribundus Blume. & Elaeocarpaceae \\
\hline & Jam & Syzygium cumini (Linn.) Skeel. & Myrtaceae \\
\hline & Kanthal & Artocarpus heterophyllus Lamk. & Moraceae \\
\hline & Peyera & Psidium guajava (Linn.) Bat. & Myrtaceae \\
\hline & Supari & Areca catech $u$ Linn. & Arecaceae \\
\hline \multirow[t]{5}{*}{ Medicinal plants } & Arjun & Terminalia arjuna $\mathrm{W} \& \mathrm{~A}$ & Combretaceae \\
\hline & Bohera & Terminalia belerica Roxb. & Combretaceae \\
\hline & Horitaki & Terminalia chebula (Gaerth.)Retz. & Combretaceae \\
\hline & Neem & Azadirachta A. Juss. & Meliaceae \\
\hline & Tentul & Tamarindus indica Linn. & Liguminosae \\
\hline \multirow[t]{4}{*}{ Horticulture } & Anaros & Annas comosus (Linn.) Marr. & Bromeliaceae \\
\hline & Kola & Musa spp. & Musaceae \\
\hline & Lebu & Citrus limon (Linn.) Burm.f. & Rutaceae \\
\hline & Papaya & Carica papaya Linn. & Caricaceae \\
\hline \multirow[t]{3}{*}{ Root crops } & Ada & Zingiber otficinale Roscoe & Zingiberaceae \\
\hline & Halud & Curcuma longa Linn. & Zingiberaceae \\
\hline & Maskolai & Phaseolus mungo Linn. & Legumominosae \\
\hline \multirow[t]{2}{*}{ Vegetables } & Morich & Capsicum frutescens Linn. & Solanaceae \\
\hline & $\operatorname{Sim}$ & Lablab purpureus (Linn.) Sweet & Fabaceae \\
\hline
\end{tabular}


five (average) pigs from the forest. Different kinds of cakes are prepared by the women.

Findings reveal that rice consumed by the Garo mainly came from the farmer's own agricultural field irrespective of farm category. Many plants, reported as being used for food, were exclusively collected from the surrounding forests (herbs and flower and fruits) and homestead. Most of the plant parts were said to be used as vegetables. Various parts of the plants were used as food evident from the survey. The use of plant parts as food by the tribal's in Chittagong Hill Tracts (CHTs) is also evident from the other studies. The young shoots of Bambusa spp. and Daemonorops jenkinsianus are used as vegetables by the tribes in CHTs, Bangladesh (Jalil and Chowdhury 2000). In some cases only one part of the plant was used, in others more than one part was edible and in some cases the whole plant is used. The mode of usage was one of the important aspects in using the forest plant. The Garo used nine plant species which were directly used as food materials (Table 3). Most of the meat consumed by the high and the medium income farmers were obtained from the market followed by low-income groups major source of meat was forest. Most of the poor farmers (45\%) followed by medium farmers $(35 \%)$ collected fish through fishing in the water bodies in and around the homestead forests.

The consumption of bamboo shoots by the tribal has a scientific basis, which was reported by Banik (1997), the average nutritional values of various bamboo shoots, with $4.5 \%$ carbohydrates, $2.6 \%$ protein, $0.3 \%$ fat and $0.9 \%$ ash; makes them a valuable, nutrient-rich source of sustenance. Young shoots of different bamboo species, especially Muli bansh (Melocanna baccifera), are cooked as vegetables. Those shoots have a bitter taste and are usually consumed in the rainy season. It is generally the new tender growth of the rhizome apex into a young Culm consisting of compressed internodes protected by a number of leathery sheaths. After removing the sheaths the inner tender portion is thoroughly washed in water, cut into pieces, cooked and consumed as a vegetable. Sometimes they are sliced and dried for use in times of food scarcity. Banik (1997) states that the young shoots of several species of bamboos are important vegetable ingredients in daily diets in China, Japan, Taiwan and Thailand. Other tribal people of Bangladesh also collect bamboo shoots from the natural forests and have traditionally used them as a major food item during rainy seasons (Barua 1995; Banik 1997; Jalil and Chowdhury 2000). Sajna (Moringa oleifera), Tentul (Tamarindus indica), Kola (Musa spp.), Kanthal (Artocarpus heterophyllus), Chalta (Dillenia indica) and, Thankuni (Centella asiatica) used as vegetables and pickles. Kola (Musa spp.) core cooked with rice is used in days of food scarcity and, chopped and mixed with bran it, makes excellent fodder for pigs and cattle (Jalil and Chowdhury 2000).

\section{Fruits consumption}

The survey reveals that fruits provide a seasonal food supply to the Garo community, especially to the children, who most frequently collected wild fruits as snacks. Our study reported that fruit was usually collected prematurely by children and the Garo generally considers fruit to be a food for children rather than for adults. Moreover, the Garo

Table 3. Food habit of the Garo tribe community in the study area

\begin{tabular}{llllll}
\hline Local name & \multicolumn{1}{c}{ Scientific name } & Family & Plant type & Using parts & Using pattern \\
\hline Chalta & Dillenia indica Linn. & Dilleniaceae & Tree & Leaves, flower, fruit & Vegetables and pickles \\
Kachu & Colacasia esculenta Schott. & Araceae & Herb & Root and leaves & Vegetables \\
Kanthal & Artocarpus heterophyllus Lamk. & Moraceae & Tree & Inflorescence and seeds & Vegetables and pickles \\
Kola & Musa spp. & Musaceae & Herb & Inner stem, flower, & Vegetables \\
& & & & inflorescence, fruits & \\
Mati alo & Dioscorea bulbifera Linn. & Dioscoreaceae & Herb & Root & Vegetables \\
Muli bansh & Melocanna baccifera (Roxb.) Kurz & Graminae & Bamboo & Young shoots and leaves & Vegetables \\
Sajna & Moringa oleifera Lamk. & Moringaceae & Small tree & Young leaves, fruit & Vegetables and pickles \\
Tentul & Tamarindus indica Linn. & Liguminosae & Tree & Young leaves, fruit & Vegetables and pickles \\
Thankuni & Centella asiatica (Linn.) Urban & Umbelliferae & Herb & Leaves & Leafy vegetables \\
\hline
\end{tabular}


Table 4. Fruit species consumption of Garo tribe community in the study area

\begin{tabular}{|c|c|c|c|c|c|c|}
\hline \multirow{2}{*}{ Local name } & \multirow{2}{*}{ Scientific name } & \multirow{2}{*}{ Family } & \multirow{2}{*}{ Parts used } & \multirow{2}{*}{ Season } & \multicolumn{2}{|c|}{ Sources (\%) } \\
\hline & & & & & Own & Market \\
\hline $\mathrm{Am}$ & Mangifera indica Linn. instead of $\mathrm{L}$. & Anacardiaceae & Inner flesh & Summer & 100 & - \\
\hline Amloki & Phyllanthus embelica Linn. & Euphorbiaceae & Outer parts & Winter & 23 & 77 \\
\hline Anaros & Annas comosus (Linn.) Marr. & Bromeliaceae & Inner flesh & Rainy & 30 & 70 \\
\hline Bel & Aegle marmelos (Linn.) Correa. & Rutaceae & Inner flesh & Spring & 60 & 40 \\
\hline Boroi & Zizyphus mauritiana Lamk. & Rhamnaceae & Outer parts & Winter & 100 & - \\
\hline Chalta & Dillenia indica Linn. & Dilleniaceae & Whole parts & Summer & 20 & 80 \\
\hline Jalpai & Elaeocarpus floribundus Blume. & Elaeocarpaceae & Outer parts & Winter & 10 & 90 \\
\hline Jam & Syzygium cumini (Linn.) Skeel. & Myrtaceae & Outer parts & Summer & 37 & 63 \\
\hline Jambura & Citrus grandis (Linn.) Osbeck. & Rutaceae & Inner flesh & Winter & 100 & - \\
\hline Kanthal & Artocarpus heterophyllus Lamk. & Moraceae & Inner parts & Summer & 100 & - \\
\hline Kola & Musa spp. & Musaceae & Inner flesh & All & 100 & - \\
\hline Lebu & Citrus limon (Linn.) Burm.f. & Rutaceae & Juice & All & 83 & 17 \\
\hline Papaya & Carica papaya Linn. & Caricaceae & Inner flesh & All & 56 & 44 \\
\hline Peyera & Psidium guajava (Linn.) Bat. & Myrtaceae & Whole parts & Rainy & 80 & 20 \\
\hline Tentul & Tamarindus indica Linn. & Leguminosae & Inner pulp, seed & Winter & 50 & 50 \\
\hline
\end{tabular}

were found to consume a total of 15 sorts of fruits species of twelve families, ranging from the smallest, Anarosh (Annas comosus), to the gigantic Kanthal (Artocarpus heterophyllus), Am (Mangifera indica) and Tentul (Tamarindus indica) (Table 4). Kanthal and Am is the only fruit tree species common to almost every household of the community. Present study took various fruits consumed by the Garo tribe into account, along with information on which parts are used, season of availability and the sources. Some fruits are seasonal and some are found all the year round. The rich Garos also buy seasonal fruits from the market. The poorer farmers derive the facility of fruit consumption from the market but they are engaged in cultivating some fruits like, Papaya (Carica papaya), Anarosh (Annas comosus), Jambura (Citrus grandis), Lebu (Citrus limon), etc. Edible wild fruits, seeds and leaves often provide food, when staple food item such as rice, buckwheat or barley are not available. The sources of fruit were recorded during the study, most of which were collected from own homestead (69\%) followed by forest (17\%) and market (14\%). Samal (1997) reveals that the Kandha tribe of Koraput, India, extracts tamarind seeds to eat. Mango stones and tamarind seeds are powdered and then made into gruel with other food items. Jana and Chauhan (2000) agree in this regard. Kumar and Goelo (2000) consider the fruits of Mahua (Madhuca indica) as the most important minor forest product. They eaten the outer coat as raw or cooked, the inner coat is dried and ground into flour, while greenish oil or butter is obtained from the kernel.

\section{Species used for energy}

Fuelwood was observed to be the only source of energy for cooking in the study area. The Garo people generally collected dried leaves, litter, twigs, fallen trees or dried branches of different trees for cooking purposes. The cooking includes both human and animal (pig) foods. They were observed to use the branches and main stem wood for this purpose and the sole source of this material is the homestead. A total of 12 plant species were used to generate energy for domestic purposes. There is no scope of collecting fuelwood from the nearby forest. In near past it was possible to go to the forest and collect fuel wood, foods etc. But presently, it is strictly prohibited by the forest department to cut down any forest trees. They collect and store fuelwood in the outer side of their house in the winter season (Table 5).

\section{Species used for Timber}

All of the houses in the Garo community in our study sample were made of bamboo, wooden posts and sun-dried grass. The trunks of certain timber species, from which the bark is stripped, serve as the main posts and major cross- 
Table 5. Plant species used for energy by the Garo tribe community of Bangladesh

\begin{tabular}{lllc}
\hline Local name & \multicolumn{1}{c}{ Scientific name } & Family & Preference $(\%)$ \\
\hline Akashmoni & Acacia auriculiformis Willd. & Mimosaceae & 93 \\
Am & Mangifera indica Linn. instead of L. & Anacardiaceae & 90 \\
Bansh & Bambusa spp. & Gramineae & 96 \\
Boroi & Zizyphus mauritiana Lamk. & Rhamnaceae & 75 \\
Dumur & Ficus hispida L.f. & Moraceae & 87 \\
Eucalyptus & Eucalyptus camaldulensis Dehnhardt. & Myrtaceae & 83 \\
Jarul & Lagerstroemia speciosa (Linn.) Pers. & Lythraceae & 94 \\
Jiga & Lannea coramandelica Houtt. & Anacardiaceae & 79 \\
Kanthal & Artocarpus heterophyllus Lamk. & Moraceae & 55 \\
Mahagoni & Swietenia mahogany (Linn.) Jacq. & Meliaceae & 68 \\
Neem & Azadirachta indica A. Juss. & Meliaceae & 67 \\
Rain tree & Samanea saman (Jaq.) Merr. & Mimosaceae & 95 \\
Sil koroi & Albizia procera Benth. & Mimosaceae & 79 \\
\hline
\end{tabular}

Table 6. Plant species used for timber by the Garo tribe community of Bangladesh

\begin{tabular}{lllc}
\hline Local name & \multicolumn{1}{c}{ Scientific name } & \multicolumn{1}{c}{ Family } & Preference $(\%)$ \\
\hline Akasmoni & Acacia auriculiformis Willd. & Mimosaceae & 93 \\
Am & Mangifera indica Linn. & Anacardiaceae & 78 \\
Eucalyptus & Eucalyptus camaldulensis Dehnhardt. & Myrtaceae & 90 \\
Gamar & Gmelina arborea (Roxb.) DC. & Verbanaceae & 80 \\
Kanthal & Artocarpus heterophyllus Lamk. & Moraceae & 80 \\
Mahagoni & Swietenia mahogany (Linn.) Jacq. & Meliaceae & 85 \\
Neem & Azadirachta indica A. Juss. & Meliaceae & 73 \\
Rain tree & Samanea saman (Jaq.) Merr. & Mimosaceae & 98 \\
Segun & Tectona grandis L. f. & Verbenaceae & 95 \\
Sil koroi & Albizia procera Benth. & Mimosaceae & 90 \\
Sissoo & Dalbergia sissoo Roxb. & Fabaceae & 68 \\
\hline
\end{tabular}

beams of their houses. A total of 11 species were reported to be used as timber (Table 6). The most common species used in construction are: Akasmoni (Acacia auriculiformis), Gamar (Gmelina arborea), Mahagoni (Swietenia mahogany), Rain tree (Samanea saman), Kanthal (Artocarpus heterophyllus), Silkoroi (Albizia procera) and Segun (Tectona grandis), etc. Sattar (1998) reported on the durability and resistance to bio-deterioration of the species used by the tribal people for timber; e.g., Gamar is dimensionally stable and shows no degradation after long periods of use. The tribes are unlikely to be aware of the scientific reason for this, but know that this is so from transmitted, traditional knowledge.

\section{Species used for Basketry and other utensils}

The survey revealed that the weaving baskets and uten- sils were an essential part and parcel of the Garo community. Most men and women weave baskets and utensils as their leisure time activities. These vary in type, size and pattern according to their probable use for various purposes such as for seeds collection and harvesting, portable baskets for potting cloths and for stationery purposes. All of these products were made mainly of bamboo (Melocanna baccifera) and canes (Calamus temiis). Amongst the everyday articles that the Garo uses the baskets, the storage pot for water was found to be an interesting utensil.

\section{Utilization of Medicinal plants}

It was evident from the survey that the Garo people greatly dependent on herbal medicine for their daily health care. Because of the inaccessibility to the modern medical 
Table 7. Medicinal plants and their using pattern by the Garo tribe community of Bangladesh

\begin{tabular}{|c|c|c|c|c|c|c|}
\hline $\begin{array}{l}\text { Local } \\
\text { name }\end{array}$ & Scientific name & Family & $\begin{array}{l}\text { Plant } \\
\text { type }\end{array}$ & Parts used & Disease & Using pattern \\
\hline Ada & $\begin{array}{l}\text { Zingiber otficinale } \\
\text { Roscoe }\end{array}$ & Zingiberaceae & Herb & Tuber & $\begin{array}{l}\text { Appetizer, dysentery, } \\
\text { cough, vomiting }\end{array}$ & $\begin{array}{l}\text { Eaten direct with salt, } \\
\text { juice of it also eaten. }\end{array}$ \\
\hline Amloki & $\begin{array}{l}\text { Phyllanthus embelica } \\
\text { Linn. }\end{array}$ & Euphorbiaceae & Tree & Leaf, bark & $\begin{array}{l}\text { Constipation, } \\
\text { jaundice, } \\
\text { spermatorrhoea }\end{array}$ & $\begin{array}{l}\text { Kept soak in water for } \\
\text { several hours. } \\
\text { Drink the water with } \\
\text { salt }\end{array}$ \\
\hline Amra & Spondias pinnata Kurz. & Anacardiaceae & Tree & Fruits, Bark & $\begin{array}{l}\text { Fever and skin } \\
\text { disease }\end{array}$ & $\begin{array}{l}\text { Juice of fruit flesh is } \\
\text { drunk }\end{array}$ \\
\hline Anaros & $\begin{array}{l}\text { Annas comosus (Linn.) } \\
\text { Marr. }\end{array}$ & Bromeliaceae & Herb & Fruit & Jaundice & Fruits are eaten \\
\hline Arjun & $\begin{array}{l}\text { Terminalia arjuna } \\
\text { W \& A }\end{array}$ & Combretaceae & Tree & Bark & Burning, dysentery & $\begin{array}{l}\text { Bark is soaked in water } \\
\text { then water is drunk }\end{array}$ \\
\hline Basok & Adhatoda vasica Nees & Acanthaceae & Shrub & $\begin{array}{l}\text { Leaves, roots, } \\
\text { flower }\end{array}$ & $\begin{array}{l}\text { Cough, asthma, } \\
\text { cardiac disease, } \\
\text { malaria }\end{array}$ & $\begin{array}{l}\text { Its juice is used with } \\
\text { piper, pipul etc }\end{array}$ \\
\hline Bel & $\begin{array}{l}\text { Aegle marmelos (Linn.) } \\
\text { Correa. }\end{array}$ & Rutaceae & Tree & Dry fruit & Gastric, flatulence & Juice from fruits \\
\hline Bon ada & $\begin{array}{l}\text { Zingiber zerumbet (Linn. } \\
\text { instead of L.) Smith. }\end{array}$ & Zingiberaceae & Herb & Roots & Typhoid, cough & $\begin{array}{l}\text { Juice from tuber is } \\
\text { served as medicine }\end{array}$ \\
\hline Debdaru & $\begin{array}{l}\text { Polyalthia longifolia } \\
\text { (Benth.) \& Hk.f. }\end{array}$ & Annonaceae & Tree & Bark & Jaundice & $\begin{array}{l}\text { Coconut water \& sugar } \\
\text { are mixed together } \\
\text { with bark juice }\end{array}$ \\
\hline Dhania & $\begin{array}{l}\text { Coriandrum sativum } \\
\text { Linn. }\end{array}$ & Umbeliferae & Herb & Leaves \& roots & $\begin{array}{l}\text { Stomach disease, } \\
\text { diarrhea }\end{array}$ & $\begin{array}{l}\text { Juice is produce from } \\
\text { leaves and roots }\end{array}$ \\
\hline Dhatura & Datura innoxia Mill. & Solanaceae & Herb & Whole plant & Diarrhea, dysentery & $\begin{array}{l}\text { Grinding to make juice } \\
\text { then drink the juice }\end{array}$ \\
\hline Durba grass & $\begin{array}{l}\text { Cynodon dactylon } \\
\text { (Linn.) Pers. }\end{array}$ & Poaceae & Herb & Whole plant & $\begin{array}{l}\text { Blood checking, } \\
\text { skin disease }\end{array}$ & $\begin{array}{l}\text { The paste from whole } \\
\text { plant is placed in the } \\
\text { wounded spot. }\end{array}$ \\
\hline Kalohalud & Curcuma caesia Roxb. & Zingiberaceae & Herb & Leaves & Itching, cholera & $\begin{array}{l}\text { Juice from leaves is } \\
\text { used. }\end{array}$ \\
\hline Kalomegh & $\begin{array}{l}\text { Andrographis paniculata } \\
\text { Nees }\end{array}$ & Acanthaceae & Herb & Whole plant & $\begin{array}{l}\text { Fever, worm, } \\
\text { dysentery }\end{array}$ & Its juice is used \\
\hline Nagdana & $\begin{array}{l}\text { Attmisia maritime } \\
\text { Linn. }\end{array}$ & Asteraceae & Big shrub & Leaves \& bark & $\begin{array}{l}\text { Weakness, women } \\
\text { disease etc }\end{array}$ & $\begin{array}{l}\text { A paste is made from } \\
\text { bark and leaves to } \\
\text { make pill. Then dried } \\
\text { pills are eaten }\end{array}$ \\
\hline Neem & $\begin{array}{l}\text { Azadirachta indica A. } \\
\text { Juss. }\end{array}$ & Meliaceae & Tree & Bark, leaves \& seed & $\begin{array}{l}\text { Fever, stomach } \\
\text { trouble, malaria, } \\
\text { diarrhea }\end{array}$ & $\begin{array}{l}\text { Pills are made from } \\
\text { grinded bark, leaves } \\
\text { and seeds. Then pills } \\
\text { are eaten regularly. }\end{array}$ \\
\hline Pathorkuchi & $\begin{array}{l}\text { Bryophyllum pinnatum } \\
\text { (Lamk) Oken. }\end{array}$ & Crassulaceae & Herb & Whole plant & Dysentery, cough & $\begin{array}{l}\text { Juice is drunk } 2-3 \\
\text { times in a day }\end{array}$ \\
\hline Piaj & Allium cepa Linn. & Liliaceae & Herb & Whole plant & Common cold & $\begin{array}{l}\text { Cutting slice is used } \\
\text { with mustered oil }\end{array}$ \\
\hline Shatamuli & $\begin{array}{l}\text { Asparagus racemosus } \\
\text { Willd. }\end{array}$ & Asparagaceae & Climber & Roots \& leaves & $\begin{array}{l}\text { Sexual weakness, } \\
\text { fever, dysentery }\end{array}$ & $\begin{array}{l}\text { The juice from roots } \\
\text { and leaves is drunk } \\
\text { regularly }\end{array}$ \\
\hline
\end{tabular}


Table 7. Continued

\begin{tabular}{|c|c|c|c|c|c|c|}
\hline Local name & Scientific name & Family & Plant Type & Parts used & Disease & Using pattern \\
\hline Sornolata & Cuscuta reflexa Roxb. & Convolvulaceae & Climber & Tender shoots & Fever, chicken disease & Juice is used \\
\hline Thankuni & $\begin{array}{l}\text { Centella asiatica } \\
\text { (Linn.) Urban }\end{array}$ & Umbelliferae & Herb & Whole plant & $\begin{array}{l}\text { Stomach disease, pain, } \\
\text { blood dysentery }\end{array}$ & $\begin{array}{l}\text { Its juice is used with } \\
\text { honey }\end{array}$ \\
\hline Tulsi & $\begin{array}{l}\text { Ocimum sanctum } \\
\text { Linn. }\end{array}$ & Labiatae & Shrub & Leaves, roots & Malaria, cough, spasm & $\begin{array}{l}\text { Juice is made from } \\
\text { leave and bark then } \\
\text { juice is drunk with } \\
1-2 \text { drop of honey }\end{array}$ \\
\hline Ulotkombal & Abroma augusta Linn. & Sterculiaceae & Shrub & leaf & $\begin{array}{l}\text { White discharge, } \\
\text { jaundice }\end{array}$ & $\begin{array}{l}\text { Juice is with sugar \& } \\
\text { salt }\end{array}$ \\
\hline
\end{tabular}

facilities due to their primitive and pristine living style, they have much dependence on indigenous medical practitioner, locally called kabiraj, who generally prepare medicine from the plants available in the homestead and give prescription to the community members who face any disease. Since they were found to be the most dependent on herbal treatment, they had a greater understanding of medicinal plant too. A total of 23 species recorded from the homestead forest garden of the Garo tribe which has medicinal value (Table 7). Most of the species were found to use curing more than one disease. Some times for a particular disease a single species were used while in many cases a maximum of the species with different proportion also used. From the result, it was found that Garo have the vast and indigenous knowledge about using herbal medicine in primary health care in their everyday lives.

\section{Gender role in daily activities of the Garo tribe com- munity}

The Garo people work together in some case and some cases there have distinct functions performed by male and female. Women do mostly the household activities and managing the homestead and helping agricultural field in sowing, mulching, weeding and harvesting. Men perform hard works like ploughing, cutting the big trees, digging the soil, preparation of the land for planting and all works in case of rice cultivation. Fuelwood collection from forest for daily cooking was the task of women. If there is no work male also collect fuel wood from the nearby forest. Female does all the activities of cottage industries except man participate in raw material collection and processing and marketing of the products. Collection of drinking water from
Table 8. Gender role of the Garo tribe community in the study area

\begin{tabular}{lcc}
\hline & \multicolumn{2}{c}{ Gender role (\%) } \\
\cline { 2 - 3 } \multicolumn{1}{c}{ Activities } & Male & Female \\
\hline Agriculture & & \\
$\quad$ Field preparation & 90 & 10 \\
Seed and planting materials collection & 80 & 20 \\
Planting, paddy cutting & 50 & 50 \\
Weeding and watering & 35 & 65 \\
Harvesting and grain separation & 50 & 50 \\
Drying and storage & - & 100 \\
Home garden and woodlot plantation & & \\
Preparing seed bed & 80 & 20 \\
Seed and planting materials collection & 30 & 70 \\
Planting & 60 & 40 \\
Weeding & - & 100 \\
Tending operation & - & 100 \\
Fuelwood collection & - & 100 \\
Cottage industries & & \\
$\quad$ Raw material collection and processing & 50 & 50 \\
Making & - & 100 \\
Marketing & 40 & 60 \\
Hunting & 90 & 10 \\
Fishing & 85 & 15 \\
Food and fruit collection & 35 & 65 \\
Marketing of food and fruit & 70 & 30 \\
Drinking water collection & - & 100 \\
\hline
\end{tabular}

the tube well, pond and carrying it to the home two times daily was also the job of women while the young girls helped their mother. The poultry was also observed to be feed and take care by the woman. Hunting and fishing was exclusively the job of men who also prepared the hunting devices and traps and is the major job performed by men. Young boys support in that job. In the preparation of horti- 
cultural and agricultural land were mostly done by men where sometimes helped by the women and young boys (Table 8).

\section{Conclusion}

The Garo community is very heavily dependent on the plants for all kinds of produce for which it finds multiple uses, the most important of which are food, fruit, energy, timber and medicine so much that they constituted one of the integral components of forest ecosystem, where they had developed a balance with nature which might be viewed as a biome, a balance between man (here the Garo themselves) on one hand and flora and fauna on the other. The purpose of this study was to provide insights of the indigenous knowledge of Garo's practiced on plain land and homestead management that would be useful to the agricultural department, relevant non-government organization, and forest department in the efforts to support their livelihoods. The indigenous knowledge on the utilization of the resources also shows a very particular pattern of forest use. They possessed an intimate relation with each and every component of forest like herbs, shrubs, trees, vines, wild animals both harmless and ferocious ones, insects, even soil and water also. Traditional dietary practices, especially involving plants, may provide important and valuable information on the medicinal effects on humans. For a full understanding of the nutrition and medicinal values of the food materials, chemical analyses need to be carried out on the respective parts of plants. Plants are also used as a source of energy; timber shows a traditional pattern of usage. To understand the scientific basis of these usages, studies on calorific values of the species used for energy, traditional use of the cooking stoves, wood structures and small scale forest based industries in the study area should be undertaken.

\section{References}

Ahmed R. 2003. The Hajong. Banglapedia, National Encyclopedia of Bangladesh. Volume-4. Asiatic Society of Bangladesh, Nimtali, Dhaka, Bangladesh.

Alam MK. 2002. Ethnobotanical knowledge and Indigenous Non-Timber Food Crops for Sustainable Development of Upland forming System in the CHT. In: Farming Practices and
Sustainable Development in Chittagong Hill Tracts (Khan NA, Alam MK, Khisa SK, eds). Chittagong Hill Tracts Development Board, Government of Bangladesh and Village and Farm Forestry Project-International Co-operation, Swiss Agency for Development and Cooperation, pp 155-163.

Alam MK, Khisa SK. 2000. The perception of Ethno botany in Chittagong Hill Tracts and its Linkage with Biodiversity. In: Of Popular Wisdom: Indigenous knowledge and practices in Bangladesh (Khan NA, ed). pp 39-46.

Anonymous. 2003. Manush, Jatigushti Parichiti (in Bangali), Series- 4. FIDDB, House-77, Road-7/A, Dhanmondi, Dhaka, Bangladesh.

Bal E. 1999. Manderangni Jagring: Images of the Garos in Bangladesh. University Press Limited, Dhaka-1000, Bangladesh.

Bal E. 2000. They ask if we eat frogs: Social Boundaries Ethnic Categorization, and the Garo People of Bangladesh. Uitgeverij Eburon Press limited, Netherlands.

Banglapedia. 2000. Netrokona district. Banglapedia: the National Encyclopedia of Bangladesh. Asiatic Society of Bangladesh, Lalmatia, Dhaka-1205, Bangladesh.

Banglapedia. 2006. The Garo. Banglapedia: the National Encyclopedia of Bangladesh. Asiatic Society of Bangladesh, Lalmatia, Dhaka-1205, Bangladesh.

Banik RL. 1997. The edibility of shoots of Bangladesh bamboos and their continuous harvesting effect on productivity. Bang Jour For Sc 26: 1-10.

Banik RL. 1998. Ethno-botany of bamboo and rattan and their Indigenous management and utilization in Chittagong Hill Tracts. In: Applied Ethno-botany (Banik RL, Alam MK, Pei SJ, Rastogi A, eds). Bangladesh Forest Research Institute, Chittagong, Bangladesh, pp 93-102.

BARUA B. 1995. Gachapala Tarulata (in Bengali). Bangla Academy, Dhaka, Bangladesh.

BBS (Bangladesh Bureau of Statistics). 2005. Bangladesh Population Census, Zilla Series: Netrokona. Ministry of Planning, Government of the People's Republic of Bangladesh, Dhaka, Bangladesh.

Bleie T. 2005. Tribal People, Nationalism and the Human Rights Challenges: the Adivasis of Bangladesh. The University Press Limited, Dhaka-1000, Bangladesh.

Burling R. 1963. Rengsanggri: Family and Kinship in a Garo Village. University of Philadelphia Press, Philadelphia.

Burling R. 1997. The Strong Women of Modhupur. University Press Limited, Dhaka-1000, Bangladesh.

Chowdhury KAN. 2007. Residence, Gender and Power in the Garo Society of Bangladesh. Doctoral Thesis. University of Dhaka, Bangladesh. (in Bangladesh)

Das DK, Alam MK. 2001. Trees of Bangladesh. Bangladesh Forest Research Institute, (BFRI). Chittagong: The Art Press, Bangladesh.

Dey TK. 2006. Useful plants of Bangladesh. 2nd ed. The Ad. Communication, Chittagong, Bangladesh. 
Haque M. 2000a: Indigenous knowledge and practices of the people of the Chittagong Hill Tracts in Bangladesh. In: Of Popular wisdom: Indigenous knowledge and practices in Bangladesh (Khan NA, ed). BARCIK/IARD, Dhaka, Bangladesh, pp 129-134.

Haque M. 2000. Environmental Issues and Concerns of the Indigenous Communities of Bangladesh. Grassroots Voice 3: 67-75.

Jalil SM, Chowdhury JK. 2000. Participatory forest Management: Implications for Policy and Human Resources Development in Bangladesh and the Chittagong Hill Tracts. In: Participatory Forest Management: Implication for Policy and Human Resources Development in the Hindu-Kush-Hiamalayas (Anupam B, ed). ICIMOD, Kathmandu, Nepal, pp 1-44.

Jana SK, Chauhan AS. 2000. Ethnobotanical aspects of legumes in Sikkim. J Non-Timber For Pro 7: 46-52.

Khisa SK. 1998. Ethno-botanical cultural background of ethnic communities in forest resource management in Chittagong Hill Tracts. In: Applied Ethno-botany (Banik RL, Alam MK, Pei SJ, Rastogi A, eds). Bangladesh Forest Research Institute, Chittagong, Bangladesh, pp 56-63.

Kumar K, Goelo AK. 2000. Ethnography of Madhuca longifolia (Koenig) Macbride: A survival Plant for the Tribes of Bihar (India). J Non-Tim For Prod 7(1-2): 59-62.

Miah MD, Chowdhury MSH. 2003. Indigenous healthcare practice through medicinal plants from forests by the Mro tribe in Bandarban region, Bangladesh. INDILINGA- African Journal of Indigenous Knowledge Systems 2: 61-73.

Miah MD, Chowdhury MSH. 2004. Traditional forest utilization practice by the Mro tribe in the Bandarban region, Bangladesh. Swiss J For 155: 65-70.

Mohiuddin M, Alam MK, Zashimuddin M. 2002. Indigenous knowledge for appropriate farming systems in Chittagong Hill Tracts. Proceedings of the appropriate soil and water conserving farming technologies for the Chittagong Hill Tracts. Organized By CHTDB, 7-8 August. Khagrachari, Bangladesh, pp 21-30.

Mustafa MM, Siddiqi MA, Khan NA, Newaz MS. 2002. An Empirical Study on the Jhum Farming System in the Chittagong Hill Tracts. In: Farming Practices and Sustainable Development in Chittagong Hill Tracts (Khan NA, Alam MK, Khisa SK, eds). Chittagong Hill Tracts Development Board, Government of Bangladesh and Village and Farm Forestry Project-International Co-operation, Swiss Agency for Development and Cooperation, pp 65-79.
Nasrin M, Khalifa MH. 2004. Bangladesher Khudro Jatisatar Ethno-botanical Onosilon (in Bangali). In: Bon, Bonbinash O Bonobasir Jibon Shangram (Gain P, ed). Society for Environment and Human Development (SEHD), Lalmatia, Dhaka-1207, Bangladesh, pp 65-101.

Partha P, Hossain ABME. 2007. Ethnobotanical investigation into the Mandi ethnic community in Bangladesh. Bangladesh J Plant Taxon 14: 129-145.

Rahman MH, Khan MASA, Fardusi MJ, Roy B, Anik SI. 2011. Forest Resources Consumption by the Patra Tribe Community Living in and around the Khadimnagar National Park, Bangladesh. Int J For Usufr Manag 12: 95-111.

Rana MP, Sohel MSI, Akhter S, Islam MJ. 2010. Ethno-medicinal plants use by the Manipuri tribal community in Bangladesh. J For Res 21: 85-92.

Rana MP, Sohel MSI, Akhter S, Hassan MR. 2009. The Use of Plants in Indigenous Health Care Practice of the Hajong Tribe Community in North Eastern Bangladesh. J For Sci 25: 25-33.

Rashid HE. 1991. Geography of Bangladesh. University Press Limited, Dhak-1000, Bangladesh.

Rashid MH, Rashid AZMM. 2002. The Prospects of Medicinal Plant Cultivation and Floriculture in the Upland Farming System. In: Farming Practices and Sustainable Development in Chittagong Hill Tracts (Khan NA, Alam MK, Khisa SK, eds). Chittagong Hill Tracts Development Board, Government of Bangladesh and Village and Farm Forestry Project-International Co-operation, Swiss Agency for Development and Cooperation, pp 165-168.

Samal J. 1997. Role of Forest in a Poor Resource Base Tribal Economy: A Micro Analysis. In: Forest Management in Tribal Areas (Mohapatra PM, Mohapatro PC, eds.). Concept publishing company, Mohan Garden, New Delhi, India, pp 105-124.

Sattar MA. 1998. Indigenous technology fir processing of forest produces. In: Applied Ethno-botany (Banik RL, Alam MK, Pei SJ, Rastogi A, eds). Bangladesh Forest Research Institute, Chittagong, Bangladesh, pp 83-84.

Siddiqi MA. 1998. Hill farming system of Marma Tribe in Chittagong Hill Tracts. MSc Thesis. Institute of Forestry and Environmental Sciences, University of Chittagong, Chittagong, Bangladesh. (in Bangladesh)

Uddin MS, Khan MFK, Khan MASA. 2009. Traditional use of medicinal plants by Garo tribe in the northern region of Bangladesh. Hamd Medi 47: 1-9. 